\title{
ElECTRONIC MATERIAL MANAGEMENT Practice on Supply Chain Performance of Sugar Processing Firms IN KenYa
}

\author{
Evans Biraori Oteki ${ }^{1}$ and Maurice Sakwa ${ }^{2}$ \\ ${ }^{1}$ Lecturer, Murang'a University of Technology, Kenya. \\ ${ }^{2}$ Senior Lecturer, Jomo Kenyatta University of Agriculture \& Technology, Kenya.
}

\begin{abstract}
The objective this study was to assess the influence of electronic material management practice on supply chain performance. The study intended to how electronic material management can support or impair the supply chain function in the process of sourcing, receiving, inventory management and order distribution to customers' satisfaction The study applied a mixed research design with a survey of 12 sugar processing firms with a population of 7,584 employees and a sample of 379 respondents drawn from management staff. Data was gathered by a questionnaire, interviews and observation. Pearson's correlation was applied to determine the relationship between electronic material management practice and Supply chain performance and regression analysis to test hypothesis. The results of model reveals that electronic material management practice has a positive influence on supply chain performance with a beta value of $\mathrm{r}=0.551, p=0.000$. The study recommends that sugar processing firms should provide their suppliers access credentials to company electronic procurement portal to increase buyer and supplier access to information to enhance electronic material management.
\end{abstract}

\section{KEYWORDS}

Electronic material management, practice, supply chain management, sugar manufacturing firms

\section{INTRODUCTION}

It is no doubt that Material Management (MM) is the engine that drives Supply Chain and Logistics of manufacturing enterprises or any other organization. With the economic development and technical progress, many Logistics are transforming from 1PL and 2PL and 3PL to 4PL and 5PL continuously, and many manufacturers are trans-forming from Mass Production to Mass Customization, and then to new manufacturing modes all the time, such as Cloud Manufacturing, Social Manufacturing etc. So, Material Management should continuously apply the latest ICT \& intelligent technologies or systems, like Barcode, RFID, IoT (Internet of Things), GPS/BeiDou Navigation Satellite System, Cloud Computing, Big data, Parallel Control and Management, to realize its transformation and upgrade coordinately with its Supply Chain and Logistics (Kahraman C. \& Çevik Onar,2015).

In the history of procurement, at one time, traditionally procurement was carried out by visiting a store and then following the procedures for placing an order or by looking through catalogues and making a phone call. The process of procurement traditionally involved manual procedures and in some point, handling procurement transactions went through slower systemic processes (Hawking et al. 2004). The traditional procurement processes are the basis for the introduction of e-procurement to the system in stages as advised by scholars of the field. Along with the 
International Journal of Managing Value and Supply Chains (IJMVSC) Vol. 11, No. 2, June 2020

emergence of internet, companies started turning their procurement activities towards internet since they found out that it would benefit them a great deal if all procurement processes are carried out correctly and properly. According to Shaw and Subramaniam (2002), e- Procurement played a vital role in business to business B2B e-commerce. Online based business to business ecommerce improves integration and inter-organizational coordination leading to cost savings in terms of transactions and great opportunities for competitive sourcing for organizations purchasing products and services. To this end, E-procurement is not only a strategic player in the value chain but also is a driver in extending supply chain networks (Hawking \& Stein 2004).

It is important to note that effective supply chains are crucial for a firm to remain competitive in today's competitive economic environment. This effectiveness is driven by striving for proper synchronization and coordination of all activities across the entire supply chain network, ranging from end-customers to suppliers. As a result, once relegated functions such as procurement, a primary determinant for the organization's relationship with suppliers become important. With this recognition, changes are currently taking place within purchasing functions of manufacturing firms, (CIPS, 2014).

With e-procurement the entire procurement process is handled online, so the company decides to make the purchases of various types, from raw materials to services, using B2B systems. Electronic tools allow enterprises to reduce the cost and time of the procurement process, improve inventory and stocks management and, consequently, this is reflected in a decisive improvement in the management of all business processes. This is a necessary solution for large companies because it makes easier and more effective the management of the entire process of purchasing and supply network, and, on the other hand, for smaller companies that, in adopting e-procurement solutions, can become part of a global business with many opportunities for growth (Centobelli \& Cerchione, 2014)

An example from countries that adopted electronic material practice indicate that using Internet technology to buy goods and services from a number of known or unknown suppliers has improved the vendor process in Australia with much improvement being realized on the part of, e-informing: Gathering and distributing purchasing information both from and to internal and external parties using Internet technology, e-market sites: Expands on Web-based ERP to open up value chains. More so buying communities can access preferred suppliers' products and services, add to shopping carts, create requisition, and seek approval, receipt purchase orders and process electronic invoices with integration to suppliers' supply chains and buyers' financial systems (Jessop, 2006).

In Kenya, there are some organizations that have successfully embraced the use of e-procurement technology. For instance Nation Media group through their digital platform commonly known as N-Soko enables their clients to purchase products online (Gitahi, 2011). According to Awino (2011), most of the SCM strategies of large manufacturing firms in Kenya are not owned by individual firms but also other organizations within the SC that provide the required linkages towards the overall corporate performance of the manufacturing industry ( Awino, 2011).

This study was driven by the fact that the history of the Kenya sugar industry has been revolving around procurement, production and distribution inefficiencies, inability to compete with imported sugar and perennial losses. Hence the supply chain function is impaired in the process of sourcing, receiving, inventory management and order distribution to customers' satisfaction. The study has bought out the significance of electronic material management practice on supply chain performance. 
International Journal of Managing Value and Supply Chains (IJMVSC) Vol. 11, No. 2, June 2020

\subsection{Statement of the problem}

Sugar processing firms in Kenya are less competitive because of low or non-application of electronics materials management in their supply chain management resulting to high costs in the supply chain management. Therefore there is need to enhance adoption of ICT in order to ensure proper functioning of the procurement system for sugar firms to effectively compete in the market. Nyaga concurs that the low electronic supply chain practices has been confirmed by previous studies that indicate that, despite e-procurement is gaining popularity due to globalization, technological changes and advancement, there are businesses that still carry out some activities manually, (Nyagah K \& Mwangangi P.,2015). To meet today's operating challenges, according to Mburu et el, (2014) technical institutions are turning to ICT to improve the services for suppliers and other customers in order to lower operating costs and improving performance.

\subsection{Objective of the study}

To assess the influence of electronic material management on supply chain performance of sugar processing firms in Kenya.

\subsection{Research hypothesis}

Ho: Electronic material management practice has no significant influence on supply chain performance of sugar processing firms in Kenya.

\section{LiteratURE REVIEW}

The study briefly introduces some of the theories applied to SCM which are borrowed from fields such as accounting, management, economics, sociology and engineering. Some of such popular theoretical models in the field of social psychology that this study is based on are Value Chain theory that considers the value addition by the inclusion of information communication technology into material management and Contingency Theory of Management that emphasizes the importance of both the leader's personality and the situation in which that leader operates, such as how management can leverage on ICT to achieve effective materials management.

\subsection{Value Chain Theory}

The theory of value chain was founded by Michael Porter in 1985 (Christopher, 1992). To better understand the activities through which a firm develops a competitive advantage and creates shareholder value, it is useful to separate the business system into a series of value-generating activities referred to as the value chain. In his 1985 book Competitive Advantage, Michael Porter introduced a generic value chain model that comprises a sequence of activities found to be common to a wide range of firms (Christopher, 1992).

In supply chains, a value chain disaggregates a firm into its strategically relevant activities in order to understand the behavior of costs and the existing and potential source of differentiation. Porter's value chain consists of a set of activities that are performed to design, produce and market, deliver and support its product. Porter distinguishes between primary activities covering inbound logistics, operations, outbound logistics, marketing and sales, service in the core value chain creating directly value and support activities including procurement, technology development, human resource management and firm infrastructure. Porter formulates the general strategies for the value chain of cost leadership and differentiation to reach competitive 
International Journal of Managing Value and Supply Chains (IJMVSC) Vol. 11, No. 2, June 2020

advantage (Porter 1985). These cross-value chain strategies established a principle that competitive advantage can be reached only by managing the entire value chain as a whole including all involved functions. Porter's value chain is one basis for the development of the supply chain. The term supply chain was created by consultant Keith Oliver in 1982. Compared to the company-internal focus of Porter's value chain, the supply chain extends the scope towards intra-company material and information flows from raw materials to the end consumer. A supply chain is a network of organizations that are involved through upstream and downstream linkages in different processes and activities that product value in the form of products and services in the hand of the ultimate consumer (Christopher, 1992). Because technology is employed to some degree in every value creating activity, changes in technology can impact a competitive advantage by incrementally changing the activities themselves or by making possible new configurations of the value chain (Simichi-Levi, 2000).

In an increasingly complex world of globalized trade with extended lead times and greater risk, the integration in the supply chain will require supporting information systems and technology. The growth of the internet and technologies which enable real-time information sharing such as inter-connected ERP systems, web-based EDI, electronic portals and online order processing systems, can potentially support the building of closer links with customers, suppliers and thirdparty vendors such as logistics service providers. In practice however, the progress towards such supply chain integration between firms has often been stalled by factors such as rival cultures, information technology deficiencies, lack of process alignment and other organizational legacies (Akkermans et al., 1999). Hence whilst this new technology offers much promise, examples of its success in transforming supply chain practice are still relatively few in number. Simichi-Levi (2000) found that companies implementing efficient production, total quality management, and reengineering strategies, will decrease costs while increasing their flexibility and quality of service. Each of these achievements, when implemented successfully, results in a competitive advantage. Ultimately, the result of these efforts has allowed managers to recognize that further improvements may be realized through supply chain management efficiencies (Poirier, 1999). To evaluate the role of information technology in supply chain management initiatives, Kumar and Dissel (1996) discuss the framework relating to the formation of cooperative alliances. They assert that organizations that normally engage in these alliances are driven by environmental forces in order to achieve a certain goal. Effective supply chain management requires information to be shared and transmitted beyond the boundaries of the organization. These information systems, expanding the availability and transfer of information between various trading partners, are called inter-organizational information systems (101S). The virtual vertical integration created by IOIS can then be used to reduce supply chain uncertainty (Kumar, 1996). Such electronic cooperation is called information partnership and focuses its attention on creating strategic value through increasing operational efficiencies (Lee, 1992). The time value and volume of information that is shared between trading partners is represented by various degrees. For example, at the highest level of an information partnership, the $101 \mathrm{~S}$ is fully disclosed to network participants (Lee, 1992).

From the theoretical framework, Electronic material management practice is explained by the Value Chain Theory. Compared to the company-internal focus of Porter's value chain, the supply chain extends the scope towards intra-company material and information flows from raw materials to the end consumer. Porter's value chain consists of a set of activities that are performed to design, produce and market, deliver and support its product. Porter distinguishes between primary activities covering inbound logistics, operations, outbound logistics, marketing and sales, service in the core value chain creating directly value and support activities including procurement, technology development, human resource management and firm infrastructure. Porter formulates the general strategies for the value chain of cost leadership and differentiation to reach competitive advantage. 
International Journal of Managing Value and Supply Chains (IJMVSC) Vol. 11, No. 2, June 2020

\subsection{Contingency Theory of Management}

The contingency theory of leadership was proposed by the Austrian psychologist Fred Edward Fiedler in his landmark 1964 article, "A Contingency Model of Leadership Effectiveness" (Northouse, 2007). The contingency theory emphasizes the importance of both the leader's personality and the situation in which that leader operates. Fiedler measured leadership style with the Least Preferred Co-Worker Scale (LPC scale.) The leaders scoring high on this scale are relationship motivated and those scoring low are task motivated (Northouse, 2007). Central to contingency theory is concept of the situation, which is characterized by three factors: Leadermember relations, deals with the general atmosphere of the group and the feelings such as trust, loyalty and confidence that the group has for its leader. Task structure, is related to task clarity and the means to task accomplishment. The position power, relates to the amount of rewardpunishment authority the leader has over members of the group (Northouse, 2007). These three factors determine the favorableness of various situations in organizations.

Northouse (2007) as a supporter of this theory highlights the major strengths of the Contingency. According to Northouse (2007), Contingency theory has survived over the decades as a valid and reliable approach how to achieve effective leadership because it is grounded in empirical research. Researchers who have followed Fiedler have validated contingency theory with their own research. Contingency theory has also been proved to have 'predictive powers' in determining the type of leadership that is most likely to be effective in particular contexts. Contingency theory suggests not to expect leaders to be equally effective in all situations and therefore organizations should consider leaders in optimal situations according to their leadership style. Contingency theory supplies data on leadership styles that could be useful to organizations in developing leadership profiles for human resource planning.

Contingency theory, although having several strengths, generally falls short in trying to explain why leaders with certain leadership styles are effective in some situations but not others. It is also criticized that LPC scale validity as it does not correlate well with other standard leadership measures. Contingency theory also fails to adequately explain what should be done about a leader/situation mismatch in the workplace (Northouse, 2007).

The contingency theory holds that circumstances play a critical role in determining the best possible response (Donaldson, 2001). Consequently, there is not good fit for all situations as other theories of management may tend to suggest. Each organization has unique circumstances and management has to tailor decision making to create best fits that address contextual issues. There are no predetermined notions that every organizations can fit into and there are no universal approaches that deliver results for every organization (Donaldson, 2001). All organizations have to attempt to uniquely respond to their circumstances and create a good fit for the emergent circumstances.

When applied to the procurement function, these theory lead to appreciation that the procuring environments are very different and unique. There are no models that are universal and can enable any organization that applies them to achieve procurement outcomes (Donaldson, 2001). While one approach works in one context or organization, the same approach would lead to failure when applied to other organizations. These are important considerations when it comes to adoption of e-material management and actual procurement practices in organizations. E-material management and procurement practices have to be adopted to fit the organizations unique circumstances thus stimulating optimal performance. 
International Journal of Managing Value and Supply Chains (IJMVSC) Vol. 11, No. 2, June 2020

If the organization does not adopt its operations to circumstances or business environment contingencies, it will not be adequately fitted for operations in a given business environment leading to failures (Donaldson, 2001). This study considers adoption of e-material management and contribution to supply chain performance. This theory informs this study in terms of evaluating the adoption processes and how that aligns e-material management practices towards stimulating procurement performance potential in an organization. The extent to which ematerial management practices are adapted to the unique procurement circumstances is the extent to which its efficiencies are likely to be realized by the organization. Some of the contingencies to consider are technology available, the capacity of suppliers or distributors and their interests, the capacity of consumers and their interests, government regulations and policy, and available capital for investment. Managers operating under the principles of contingency theory have to do more than just identify the one or two influences on an issue. They have to be prepared to evaluate multiple inputs that may all be contributing to a problem. Using the example of long lead times leading to poor deliveries, the manager may discover that not only non-application of electronic material management contribute to the problem, but the company's revised payment program, poor procurement team coordination, a loss of supplier recognition and outdated application of outdated e-procurement policy all contribute to the single problem. Contingency managers have to learn to integrate all of the threads that intertwine to make for effective decisions and problem-solving.

From the theoretical framework, supply chain performance is linked to the contingency theory of leadership. Supply chain management aims at linking each element of the manufacturing and supply processes from raw materials acquisition, processing of goods and up to the final end users of the product. It focuses on how firms utilize their suppliers' processes, technology and capability to enhance competitive advantage. The objectives of the supply chain are to provide service to customers, achieve low operating costs and minimize the assets in the chain. Companies should be looking at securing cost, quality, technology and other competitive advantages as strategies to pursue in a globally competitive environment and to achieve this many manufacturers are focusing on their supply chain management practices.

\subsection{Conceptual Framework}

The independent variable conceptualized has having influence on the performance of supply chain was electronic material management practice. In terms of logistics, the main problems are wrong time of materials arriving to the site or even wrong quality, lack of information for materials arrival to the site or site stock, missing materials, unavailability of storage space, and waste of labour for materials searching on site. Electronic material management has an effect on materials management in knowing real time stock levels availability to assist in planning, easily establishing inventory carrying cost to institute control, reducing or eliminating errors of order transmission and electronic stock management helps to detect surplus inventory. The effect of electronic materials management is either positive with its application or negative for lack of it. Technology can help to improve the tracking and delivery of the materials. With the application of technology, consideration is given to how GPS (movement of stocks in the supply chain), JIT (real time stock levels), EOQ (inventory carrying costs) can be used in adding values in the process of using E-material management in the supply chain to improve performance. The above statements are shown by the conceptual frame in figure 1.1 below. 


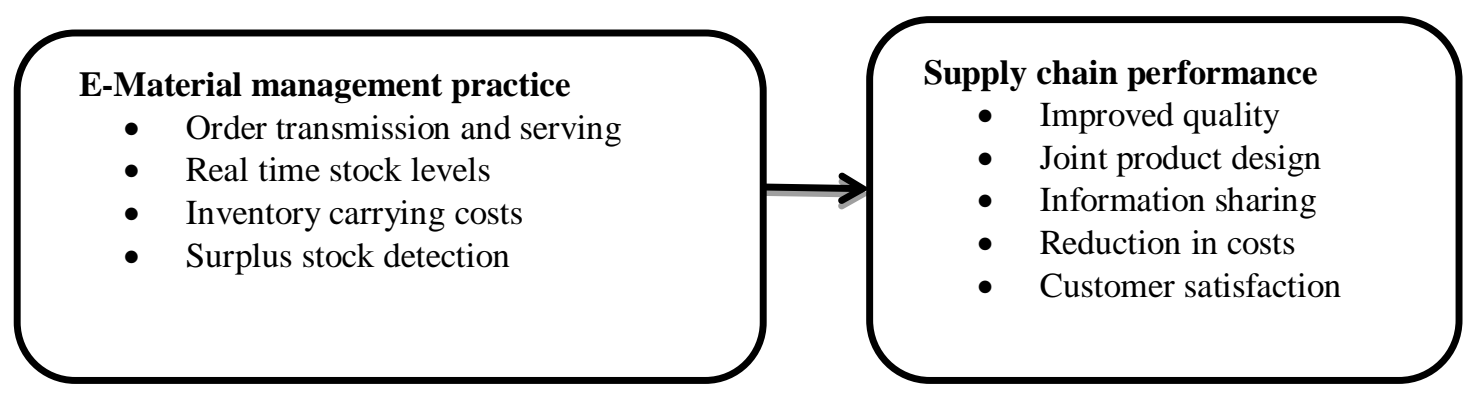

Figure 1.1 Conceptual Framework

\subsubsection{Electronic Material Management Practice}

In the value chains, to reduce costs and increase efficiency, most organizations have turned to lean supply chain management which is a comprehensive production management system initially developed by Toyota in Japan but later perfected by other scholars and organizations that supports elimination of waste and reduction of error reduced inventories costs thus bringing about efficiency and effectiveness. With the introduction of concepts like JIT (Just in Time) and VMI (vendor managed inventory), it is paramount that best practice organizations introducing lean supply chain management practices identify strong suppliers and develop those suppliers into partners. According to a report by Klynveld Peat Marwick Goerdele, diverse supplier base and mentoring of suppliers by the buyer means that efficiency and effectiveness is achieved in service delivery. When conducting a new supplier appraisal whether electronic or manual, assessment emphasis is put on product quality, planning, supply assurance, customer focus and change control, (KPMG, 2012),

A supply chain of a certain product or a service essentially has three main parts, the supply, manufacturing and distribution. The supply side concentrates on how, where from and when raw materials are procured and supplied to manufacturing. Manufacturing converts these raw materials to finished products and Distribution ensures that these finished products reach the final customers through a network of distributors, warehouses and retailers. Effectively managing these flows can impact virtually all e-material supply chain, leading to profitable policies for continuous improvements in areas such as data accuracy, improving material quality, reducing lead times and reductions in operational complexity. Other benefits include: Improved delivery performance such as quicker customer response and fulfillment, rates especially in the field of IT which is changing very rapidly, greater productivity and lower costs, reduced inventory throughout the chain, improved forecasting precision of demand, enhanced inter-operational communications and cooperation and more reliable financial information, (Lambert et al., 1998). Throughout the process, supply chain management planning tools are intended to integrate the resource planning activities in a firm or organization. Some of the most common planning tools are: material requirement planning (MRP), manufacturing resources planning (MRPII), and Enterprise Resource Planning (ERP). A MRP is a tool that allows an organization to schedule production activities to meet specific deadlines based on the bill of materials, inventory levels, and master production schedule. An improvement of MRP tools is MRPII which integrates manufacturing capabilities and capacities with the benefits of MRP. An ERP tool allows the organization to integrate all processing information tasks related to all processes in the value chain. This is usually a single system that might include order management, inventory fulfillment, production planning, financial planning, and customer service in a company. It is the backbone of the logistic systems for a variety of firms (Bowersox et al., 2007). Some other IT 
International Journal of Managing Value and Supply Chains (IJMVSC) Vol. 11, No. 2, June 2020

tools exist that can be used to execute or manage the various activities and relationships in the entire supply chain. These may include: data warehouse (DW), vendor managed inventory (VMI), distribution requirement planning (DRP), and customer service management (CRM). Eprocurement support JIT and allows purchasing managers to make informed decisions on EOQ, reorder point and stock levels, (Kumar 2001).

Materials management is an essential function that improves productivity in projects. Hence, the efficient use and management of material have an important influence on a company's profit and can avoid delays. In terms of purchasing and supply of materials, not matching materials with the ordering purchase, forgetting ordering materials, over or less materials, early or late materials arriving, lack of JIT strategy, lack of training and adequate management, lack of communication and relation between contractor and supply chain companies are the main obstacles. Some common problems on material management are more obvious which are namely: Failure to order on time which delays the projects; Delivery at the wrong time which interrupts the work schedule; Over ordering; Wrong materials or error in direction of materials requiring re-work; Theft of materials from delivery into production; Double handling of materials because of inadequate material handling techniques. In terms of logistics, the main problems are wrong time of materials arriving to the site or even wrong quality, lack of information for materials arrival to the site or site stock, missing materials, unavailability of storage space, and waste of labour for materials searching on site. Technology can help to improve the tracking and delivery of the materials. Consideration can be given to how GPS, JIT, EOQ can be used to in managing the process using E-material management, (Sushil G. \& Martin S., 2014).

\subsubsection{Supply Chain performance}

Supply Chain Performance is defined to as the extended supply chain's activities in meeting endcustomer requirements, including product availability, on-time delivery, and all the necessary inventory and capacity in the supply chain to deliver that performance in a responsive manner, (Kluwer, 2004). Supply chain performance has come to the limelight for reasons such as, supply chains are very complex business networks that need to be managed collaboratively and optimized globally, additionally, global business landscape is constantly and rapidly changing, also the uncertainty, growing competition, shorter cycle times, more demanding customers, and pressure to cut costs are just a few characteristics of the 21st century business environment. Hence it has become critical to measure, track, and manage the performance of supply chain processes. Performance management relates to application of processes, methods, metrics, and technologies in order to create a consistent relationship between supply chain strategy, planning, implementation, and controlling, (Hindawi Publishing Corporation, 2014).

Procurement performance is the backbone of an organization success since it contributes to competitive purchase and acquisition of quality goods that puts the organization products or services in the competitive edge in the market. However, on several occasions, poor procurement performance has caused private and public sectors financial loss due to delivery of poor quality work materials, loss of value for money and inflated prices. Poor procurement performance also contributed to decrease of profitability of private sector (Juma, 2010). According to (Migai, 2010), poor procurement performance is a major hindrance to private sector organizations growth since it causes the delay of delivery, increase of defects, delivery of low quality goods or nondelivery at all. Poor procurement performance in the private sector has been a problem due to incompetent staff, traditional procurement procedures, and inability to embrace e-procurement, poor coordination of procurement activities, lack of quality assurance policies and lack of proper regulations (Juma, 2010). 
International Journal of Managing Value and Supply Chains (IJMVSC) Vol. 11, No. 2, June 2020

Good performance measures need to determine the gap between actual and targeted performance and determine organization effectiveness and operational efficiency. Ideal measures of performance will lead to the attainment of double benefits-improvement of supply chain management and effective measurement of the achieved benefits. The performance measure can be grouped in to two; those that concentrate on financial measures such as profit return on investment and productivity. Also there are those measures that put more emphasis on less tangible and non-financial measures in performance measurements. Financial performance measure while important to shareholder, it provides too little information regarding the long-term effectiveness of firm in satisfying customers and hence the many organizations have successfully used product quality and customer service capabilities measures (Wisner et al., 2010).

\section{RESEARCH METHODOLOGY}

This study employed mixed research design. The population for this survey included all the 12 sugar companies in Kenya. Yamane (1967:886) formula was applied to get sample size of 379 identified randomly from each of the 12 factories. Primary data was collected by questionnaire, interview guide and observation. Secondary data was used to depict pertinent issues which existed before the study was conducted; it was used as a basis to confirm/contrast further findings of the study. Quantitative data was analyzed using descriptive statistical tools such as mean, mode and standard deviation. Multiple regression analysis was applied to analyze the relationship between the dependent variable and independent variable. The results were fitted in the regression model, $\mathbf{Y}=\boldsymbol{\beta}_{\mathbf{0}}+\boldsymbol{\beta}_{1} \mathbf{x}_{1}+\boldsymbol{\varepsilon}$, Where: $\mathrm{Y}=$ Supply chain performance, $\mathrm{B}_{0}, \mathrm{~B}_{1,}$, regression coefficients to be estimated, $\mathrm{X}_{1=\mathrm{E}} \mathrm{E}$-material management practice and $\varepsilon=$ error term.

\section{RESEARCH FINDINGS AND DISCUSSION}

\subsection{Electronic Material Management Practice}

In gathering insights on electronic material management, respondents were asked to indicate their opinion whether E-material management practice enhances supply chain performance, where in response majority at $97.7 \%$ were of the view that E-material management practice enhances supply chain performance while $2.3 \%$ had a contrary view as shown in Table 1.1. This concurs with the findings of Bagaka .C \& Moronge. M, (2017) that implementation of electronic materials procurement tool positively influenced the performance of sugar manufacturing industries in Kenya.

Table 1.1 whether electronic material management enhances SC performance

\begin{tabular}{|c|c|c|}
\hline Response & Frequency & Percent \\
\hline No & 6 & 2.3 \\
\hline Yes & 260 & 97.7 \\
\hline Total & 266 & 100.0 \\
\hline
\end{tabular}

\subsection{Results of Electronic Material Management Practice on SC Performance}

Statements on electronic material management responses indicated that, E-material management practice affects supply chain performance positively in that real-time stock levels enable inventory manager to quickly see which products have reached re-order level to start ordering process (mean of 4.43 that is closer to a maximum of 5 in the measure scale). Further the study established that Inventory levels of each item in a warehouse or in each warehouse if multiple is 
International Journal of Managing Value and Supply Chains (IJMVSC) Vol. 11, No. 2, June 2020

accessible to management for quick decision making (mean 4.28). The study found out that Ematerial management practice enables count of inventory throughout the supply chain from one central point (mean 4.11). Respondents indicated to a moderate extent that by use of Bar codes store's inventory was automatically adjusted to account for items that left the store (mean 3.94). The findings also to a significant level indicate that E-material management practice minimizes inventory carrying costs as electronic information enabled better decisions on reorder quantities and delivery (mean 4.17). Respondents highly agreed that visibility of product availability was critical to efficient operations of the firm (mean of 4.11). A summary of the findings of electronic material management practice are indicated in Table 1.2.

Table 1.2 Electronic material management practice

\begin{tabular}{lccc}
\hline Statement on electronica material management(EMM) & $\mathrm{N}$ & Mean & Std. Dev. \\
\hline $\begin{array}{l}\text { By application of EMM, real-time stock levels enable } \\
\text { inventory manager to quickly see which products have } \\
\text { reached re-order level. }\end{array}$ & 266 & 4.43 & 0.66 \\
$\begin{array}{l}\text { By application of EMM, Inventory levels in each warehouse is } \\
\text { accessible to management }\end{array}$ & 266 & 4.28 & 0.80 \\
$\begin{array}{l}\text { Application of EMM enables count of inventory throughout } \\
\text { the supply chain }\end{array}$ & 266 & 4.11 & 0.90 \\
$\begin{array}{l}\text { Application of EMM enables use of Bar codes to automatic } \\
\text { inventory adjustment to account for items leaving the store. }\end{array}$ & 266 & 3.94 & 1.05 \\
$\begin{array}{l}\text { Application of EMM minimizes inventory carrying costs as } \\
\text { electronic information enables better decisions on reorder }\end{array}$ & & & \\
$\begin{array}{l}\text { quantities. } \\
\begin{array}{l}\text { By application of EMM visibility of product availability } \\
\text { which is critical to efficient operations. }\end{array}\end{array}$ & 266 & 4.17 & 0.85 \\
\hline
\end{tabular}

\subsection{Results of Supply Chain Performance}

In compiling opinions on supply chain performance metrics, findings indicate that majority of the respondents agreed to a large extent that the application of E-materials management practices reduces procurement costs as indicated by a mean score of 4.43. Further, it is evident EMM improves efficiency and time taken to complete procurement process with a mean of 4.52. Further EMM enhances standardized purchasing processes across the organization with a mean score of 4.31. Also respondents agreed that EMM had resulted to reduced administrative cost with better effectiveness (mean 4.22). Respondents indicates also that EMM had improves effectiveness of SC processes (mean 4.24). Results indicates that EMM lowers discretion of marvelik purchases and thus increased transparency (mean 4.27). EMM also enhances SC mangers decision making (mean 4.18) and the EMM practices had made possible reduced errors of order transmission (mean 4.20). However, respondents also indicated that EMM practice had slightly reduced procurement corruption and inventory levels as indicated by the mean score of 3.85 and 3.94 respectively as shown by table 1.3. This study concurs with Wolcott (2010) that inventory Management systems and inventory control processes provide information to efficiently manage the flow of materials, effectively utilize people and equipment, coordinate internal activities and communicate with customers (Wolcott, 2010). The study also concurs Gitau R. (2016) findings which revealed that inventory management practices enhances continuous production and reduces resource wastage, reduces production costs and reduces delivery lead time and prevents shortages and stock out costs and minimizes machine down time. 


\begin{tabular}{lccc}
\hline $\begin{array}{l}\text { Statement on electronic material management (EMM) practice } \\
\text { of supply chain performance }\end{array}$ & N & Mean & Std.Dev \\
\hline $\begin{array}{l}\text { Application of EMM reduces purchasing costs } \\
\begin{array}{l}\text { Application of EMM improves efficiency and time taken to } \\
\text { complete procurement process }\end{array}\end{array}$ & 266 & 4.43 & 0.74 \\
$\begin{array}{l}\text { Application of EMM enhances standardized purchasing } \\
\text { process across the organization }\end{array}$ & 266 & 4.52 & 0.62 \\
$\begin{array}{l}\text { Application of EMM, Reduces administrative cost with better } \\
\text { effectiveness }\end{array}$ & 266 & 4.22 & 0.69 \\
$\begin{array}{l}\text { Application of EMM improves effectiveness of SC processes } \\
\begin{array}{l}\text { Application of EMM limits discretion purchases \& increases } \\
\text { transparency }\end{array}\end{array}$ & 266 & 4.24 & 0.80 \\
$\begin{array}{l}\text { Application of EMM improves SC mangers decision making } \\
\begin{array}{l}\text { Application of EMM achieves reduction in errors of order } \\
\text { transmission }\end{array}\end{array}$ & 266 & 4.27 & 0.83 \\
$\begin{array}{l}\text { Application of EMM reduces procurement corruption } \\
\text { Application of EMM leads reduction in surplus inventory }\end{array}$ & 266 & 4.20 & 0.78 \\
\hline
\end{tabular}

\subsection{Correlation Analysis for Electronic Material Management Practice}

Findings indicate that there is a strong, positive correlation between supply chain performance and E-material management practice, that is statistically significant at $(r=.551, n=266, p=$ .000 ). These findings confirm that there is a positive linear relationship between supply chain performance and E-material management practice.

The Hypothesis on EMM postulated that,

$\boldsymbol{H o}_{1}$ : E-material management practice has no significant influence on supply chain performance of sugar firms in Kenya.

To evaluate the statement, the results of multiple regressions reveals that electronic material management has a beta value of $r=.551$ and a $p=.000$. Since the $\mathrm{p}$ - value is less than $<0.05$, the null hypothesis is rejected. Hence it is then concluded that there is significant relationship between electronic material management practice and supply chain performance as presented in table 1.4.

Table 1.4 Correlation for electronic material management

\begin{tabular}{lccc}
\hline & & $\begin{array}{c}\text { Supply chain } \\
\text { performance }\end{array}$ & $\begin{array}{c}\text { E-material } \\
\text { management }\end{array}$ \\
\hline Supply chain performance & Pearson correlation & 1 & $.551^{*}$ \\
& Sig. (2-tailed) & & .000 \\
Electronic material management & $\mathrm{N}$ & 266 & 266 \\
& Pearson correlation & $.551^{*}$ & 1 \\
& Sig. (2-tailed) & .000 & 266 \\
\hline
\end{tabular}

**Correlation significant at the 0.01 level (2-tailed) 


\subsection{Model Summary of Electronic Material Management}

The model for the construct customer service was tested. The coefficient of determination and $\mathrm{R}=.0 .551 \mathrm{R}$ Square $=0.304$ at 0.05 at significance level. The coefficient of Determination $(\mathrm{R} 2$ Square) of 0.304 postulates that $30.4 \%$ of the procurement performance of the sugar processing firms can be attributed to the electronic material management practices they have adopted in their procurement processes. This shows that there existed a positive correlation coefficient between E- material management and supply chain performance. The findings as indicated in table 1.5.

Table 1. 5 Model summary electronic material management

\begin{tabular}{cccccc}
\hline Model Summary & & & \\
\hline Model & $\mathrm{R}$ & $\mathrm{R}$ & $\begin{array}{c}\text { Adjusted R } \\
\text { Square }\end{array}$ & $\begin{array}{c}\text { Std. Error of } \\
\text { the Estimate }\end{array}$ \\
\hline & 0.551 & 0.304 & 0.301 & 0.471 \\
\hline
\end{tabular}

a. Predictors: (Constant), E-material

management practice

\subsection{ANOVA for Electronic Material Management}

The probability value of 0.000 indicates that the regression relationship is highly significant in predicting how E-material management affects supply chain performance of sugar firms. The $\mathrm{F}$ calculated at $5 \%$ level of significance was 115.425 and since $\mathrm{F}$ calculated is greater than the $\mathrm{F}$ critical (value $=5.1922$ ), this shows that the overall model is significant. The finding of electronic material management are shown in table 1.6.

Table 1. 6 ANOVA for electronic material management

\begin{tabular}{llccccc}
\hline Model & & $\begin{array}{c}\text { Sum of } \\
\text { Squares }\end{array}$ & df & $\begin{array}{c}\text { Mean } \\
\text { Square }\end{array}$ & F & Sig. \\
\hline \multirow{2}{*}{1} & Regression & 25.509 & 1 & 25.509 & 115.425 & .000 \\
& Residual & 58.470 & 264 & 0.221 & & \\
& Total & 83.979 & 265 & & & \\
\hline
\end{tabular}

a. Predictors: Constant, E-

material

b. Dependent: Y

\subsection{Regression for Electronic Material Management}

The regression equation is presented as follows; Supply chain Performance $=2.255+0.464$ (Ematerial management).The regression model has established that supply chain performance will equal to 2.255 when E-material management equal to zero. Supply chain performance is predicted to improve by 0.464 when E-material management goes up by one unit. At $5 \%$ level of significance and $95 \%$ level of confidence, E- material management practice had p-value of 0.000 level of significance indicating that E-material management is statistically significant $(p<0.05)$. The predictor (E-material management) has a low p-value hence it is likely to be a meaningful addition to the model because changes in the predictor's value are related to changes in the response variable. Table 1:7 provides the information of E-material management. 
International Journal of Managing Value and Supply Chains (IJMVSC) Vol. 11, No. 2, June 2020

Table 1.7 Regression for electronic material management

\begin{tabular}{lccccc}
\hline & $\begin{array}{l}\text { Unstandardized } \\
\text { Coefficients }\end{array}$ & $\begin{array}{c}\text { Std. } \\
\text { Error }\end{array}$ & $\begin{array}{l}\text { Standardized } \\
\text { Coefficients Beta }\end{array}$ & t & Sig. \\
\hline $\begin{array}{l}\text { (Constant) } \\
\begin{array}{l}\text { Electronic } \\
\text { management }\end{array}\end{array}$ & 2.255 & 0.183 & & 12.336 & .000 \\
\hline
\end{tabular}

a. Dependent: SCP

\section{SuMMARY, CONCLUSION AND RECOMMENDATIONS}

\subsection{Summary}

From the study it is established that electronic material management enhances supply chain performance, majority $97.7 \%$ were of the view that electronic material management enhances supply chain performance while $2.3 \%$ had a contrary view. To a large extent electronic material management practice affects supply chain performance in that real-time stock levels enable inventory managers to quickly see which products have reached re-order level, Inventory levels in each warehouse is accessible to management, enables count of inventory throughout the supply chain, minimizes inventory carrying costs as electronic information enables better decisions on reorder quantities and visibility of product availability is critical to efficient operations. Some respondents indicated that by use of Bar codes store's inventory can be automatically adjusted to account for items leaving the store affects procurement performance to a moderate extent.

\subsection{Conclusion}

It is concluded that there is significant relationship between electronic material management practice and supply chain performance with $r=0.551, p=0.000$. Since $p$ value, 0.000 is $<0.05$, the null hypothesis was rejected. Hence E-material management practice enhances supply chain performance in that real-time stock levels enable inventory manager to quickly see which products have reached re-order level, inventory manager Knows how much inventory is in each warehouse, enables count of inventory throughout the supply chain, minimizes inventory carrying costs as electronic information enables better decisions on reorder quantities and visibility of product availability is critical to efficient operations.

\subsection{Recommendations}

\subsubsection{Managerial Recommendations}

From the study establishes that electronic material management practice enhanced supply chain performance by Stocks being managed by application of MRP, EOQ, stock aging, stock location, receiving, issuing stocks and stock reports electronically. It is recommended that application of Bar codes should be improved to improve receipts and issues of stocks.

\subsubsection{Policy Recommendations}

The sugar processing firms should provide the supplier with access credentials for the supplier portal. This will increase user's access to information in the electronic material management process with effective internet and thus an increase in chances of improved material management 
International Journal of Managing Value and Supply Chains (IJMVSC) Vol. 11, No. 2, June 2020

practice covering raw material, logistics and goods in process, finished goods and distribution management.

\section{REFERENCE}

[1] Akkermans, Bogerd and Vos (1999). Virtuous and vicious cycles on the Road towards international Supply Chain Management. International journal of operations and production management, 565581 .

[2] Awino (2011). An empirical investigation of selected strategy variables on firm's performance: A study of supply chain management in large private manufacturing firms in Kenya, Journal of Public Administration and Policy Research Vol. 3, 228-236.

[3] Awino, B. (2007). The Effect of Selected Strategy Variables on Corporate Performance: A Survey of supply chain management in large private Manufacturing firms in Kenya. Unpublished PhD Thesis, University of Nairobi.

[4] Bagaka .C \& Moronge. M, (2017), role of material management on performance of sugar manufacturing industries in kenya case of mumias sugar company limited, The Strategic Journal of Business \& Change Management. ISSN 2312-9492(Online) 24148970(Print).www.strategicjournals.com, 2017.

[5] Centobelli \& Cerchione (2014). E-procurement and E-supply Chain: Features and Development of Ecollaboration. International Conference on Future Software Engineering and Multimedia Engineering. (2014)

[6] Chartered Institute of Purchasing and Supply, (2014). http://www.cips.com/ Accessed October 15, 2012

[7] Christopher, M. (1992). Logistics and Supply Chain Management. Pitman

[8] Donaldson, L., 2001. The Contingency Theory of Organizations, Sage, Thousand Oaks.

[9] Gitahi, L. (2011). "Exceptional Customer Relationship is the Key to Our Success" Nation Builder Newsletter.

[10] Gitau R. W., (2016). Inventory management practices and organizational productivity in parastatals in Kenya, Thesis, Retrieved https://pdfs.semanticscholar.org/b99c/63e4f677795e176193f854ee7ceb2200e02f.pdf, 2018.

[11] Hausman W.H. (2017), Supply Chain Performance Metrics. In: The Practice of Supply Chain Management: Where Theory and Application Converge. International Series in Operations Research \& Management Science, vol 62. Springer, 2017, Boston, MA

[12] Hawking, P., Stein, A., Wyld, D. C., \& Foster, S. (2004). E-procurement: is the ugly duckling actually a swan down under? Asia Pacific Journal of Marketing and Logistics, 16(1), 3-26.

[13] Hindawi Publishing Corporation, (2014). Scientific World Journal Volume 2014, Article ID 528917, 17 pages http://dx.doi.org/10.1155/2014/528917

[14] Jessop B. (2006). Principal of Management, 8th Edition, Mc Graw Hill Publishing Company Ltd, New Dehli, India

[15] Juma, M.J. (2010). Lead from where you are: Quarterly PPO Bulletin (4)1. Nairobi: A publication of Non-Governmental Organizations Procurement Oversight Authority.

[16] Kahraman C., Oztayşi B., Uçal Sarı İ., Turanoğlu E.(2014). Fuzzy Analytic Hierarchy Process with Interval Type 2 Fuzzy Sets, Knowledge Based Systems, 59, 48-57.

[17] Kahraman, C., Cevik Onar, S., and Oztaysi, B. (2016) A Comparison of Wind Energy Investment Alternatives Using Interval-Valued Intuitionistic Fuzzy Benefit/Cost Analysis, Sustainability, 8, 118

[18] [25]. Kluwer, (2004). The Practice of Supply Chain Management: Where Theory and Application Converge, Pages 61-73

[19] Kumar, K., Dissel, H., (1996). "Sustainable Collaboration: Managing Conflict and Cooperation in Inter-organizational. Systems", MIS Quarterly, Minneapolis, Vol. 20, Issue 3, pp. 279-300

[20] Kumar, R. and Connie, C. (1999). Educating Senior Management on the Strategic Benefits of Electronic Data Interchange, Journal of Systems Management

[21] Lambert, D. M., Cooper, M. C., \& Pagh, J. D. (1998). Supply chain management: implementation issues and research opportunities. The international journal of logistics Management, 9(2), 1-20.

[22] Lee, S., Leifer, R., (1992). "A Framework for Linking the Structure of Information Systems with Organizational Requirements for Information Sharing", Journal of Management Information Systems, Armonk, Vol. 8, Issue 4, pp. 27-42 
International Journal of Managing Value and Supply Chains (IJMVSC) Vol. 11, No. 2, June 2020

[23] Mburu, S. Njeru, A. (2014). Factors Affecting Procurement Performance in the Milk Processing Firms in Kiambu County. International Journal of Science and Research. ISSN (Online): 2319-7064

[24] Northouse, P. G. (2007). Leadership: theory and practice. 4th ed. Thousand Oaks, CA: Sage Publications.

[25] Nyagah K \& Mwangangi P., 2015. Influence of e-procurement implementation on supply chain performance in dairy industry in kenya: a case of new kcc limited, International Journal of Innovative Social Sciences \& Humanities Research 3(2):31-47, April-June 2015.

[26] Poirier, C, (1999). "Advanced Supply Chain Management: How to Build a Sustained Competitive Advantage", Berrett-Koehler, San Francisco, CA.

[27] Porter M. E., (1999). Microeconomic competitiveness: Findings from the 1999 Executive Survey., (Geneva: World Economic Forum, Global Competitiveness Report)

[28] Porter, M, (1993). "Differential Strategy," Harvard Business Review, Vol. 74, number 6, 61Procurement strategies: A relationship Based approach, Blackwell Publishing, Oxford.

[29] Porter, Michael E. (1985). Competitive Advantage. Creating and Sustaining Superior Performance. The Free Press. New York power plant (2012) S. P. Nangare, R. S. Kulkarni

[30] Simchi-Levi, D., Kaminsky, P \&Simchi-Levi, E. (2010). Designing and Managing the Supply Chain: Concepts, Strategies, and Case Studies. Boston, MA: McGraw-Hill.

[31] Sushil G. and Martin S., (2014). Production and Operations Management Systems, CRC Press is an imprint of Taylor \& Francis Group, an Informa business. International Standard Book Number-13: 978-1-4665-0734-0 (eBook - PDF).

[32] Wolcott, H. (2010). Logistics and Supplies Management, Pearson Education Ltd. England

[33] Yamane Taro. (1967). Statistics: An Introductory Analysis, 2nd Ed., New York: Harper and Row. 